engaged in all branches of the profession in the future, and the consequential intake of medical students required" (H.M.S.O., 2s. 6d. net). Excluding students from overseas, the present annual output of qualified men from the medical schools of the United Kingdom is 1,855. Allowing for losses due to natural causes, the Committee's view is that from 1962 until about 1975 a smaller number will suffice to meet all estimated needs, and that in consequence the intake of medical students should be reduced by about 10 per cent as soon as practicable. On the other hand, the Committee also believes that by about 1975 more doctors are likely to be needed, and that consequently the student intake should be raised from about 1970 . This forecast is necessarily speculative, and the prudent suggestion is made that another review should be made in about ten years time.

In the meantime, it would seem inevitable that the result of these recommendations will be to generate no small measure of despondency and alarm among the scientists in our medical schools. There are 1,200 or so "whole-time university medical teaching and research staff", and the Willink Committee seems to have accepted a quite arbitrary opinion of the Committee of Vice-Chancellors and Principals that these figures should not increase by more than 1 per cent a year. One can only hope that the University Grants Committee will pay little attention to a piece of advice the effect of which can only be to help stifle a body of research workers who number among themselves some fifty Fellows of the Royal Society and two recent Nobel Prize winners.

Department of Scientific and Industrial Research

IN reply to a question in the House of Commons on December 17 regarding progress with the fiveyear plan of the Department of Scientific and Industrial Research, Mr. H. Nicholls, Parliamentary Secretary to the Ministry of Works, representing the Lord President of the Council, said that the first three and a half years of the plan had been completed and the activities of the Department are developing broadly along the lines planned. At the end of 1957-58 it is estimated that the staff will have increased by 750 out of the 800 planned, although the Department has not been able to recruit all the specialist staff needed. The provision of new buildings has also fallen behind, largely owing to restriction on capital expenditure, and by the end of 1957-58 only half the planned building programme will have been completed. Plans for the period 1959-64 are at present in preparation and are being considered by the Council for Scientific and Industrial Research.

In reply to a further question, Mr. Nicholls said that there are close direct contacts between the nine research associations serving the textile industries. Ten years ago the Department established a Standing Consultative Conference on Textile Research to avoid undesirable duplication and to promote collaboration among the research associations, or equivalent organizations engaged in textile research, whether in receipt of a grant-in-aid from the Department or not. He thought there was no doubt that the Conference, which meets every year, its effective committee meeting quarterly, has justified its existence.

Questioned about the Department's postgraduate training grants, Mr. Nicholls said that the Council has set up a Postgraduate Training Grants Committee under the chairmanship of Sir Eric Ashby consisting of three members appointed after consultation with the Committee of Vice-Chancellors and Principals of
Universities ; one member representing the technical colleges ; and professors of high standing in the main broad fields of science and technology, together with the chairman of the University Grants Committee and a Ministry of Education representative as assessors.

\section{Study of Dentine}

TEETH consist of a surface layer of enamel and a core of dentine which also forms the root. The dentinal matrix is permeated by canaliculi which, according to the usually accepted view, contain cytoplasmic strands originating from odontoblasts within the pulp cavity. An alternative view about the contents of the tubules was advanced as long ago as 1879, but the classical description does not appear to have been challenged until 1954 when Dr. W. Warwick James published a preliminary account of work which led him to believe, first, that the dentinal tubules open into the pulp cavity between adjacent odontoblasts; secondly, that they contain tissue fluid; and thirdly, that odontoblasts are concerned with the production of the collagenous fibres and mucopolysaccharides of the dentinal matrix. A full report of Dr. James's observations has recently been published in the Transactions of the Zoological Society of London (29, Part 1; 1957) in the form of a lavishly illustrated monograph. Introductory sections summarize earlier views about the structure of dentine and lead to descriptions of the histological appearance of the tissue as seen in the conventional type of preparation from the teeth of mammals (twenty-two species at various stages of development) ; reptiles (seven species); amphibians (one species); and fish (ten species). Dr. James develops the thesis that the dentinal tubules originate as a result of mechanical forces set up as adjacent odontoblasts produce columns of fibrous matrix in a space permeated by tissue fluid and enclosed by the cells of the internal dental epithelium. He concludes with an account of some of the physical properties of dentine, and suggests that the high elasticity of the tissue accounts for its peculiar sensory characteristics.

\section{Biotopes of Ruwenzori}

IN the second series of monographs on the Exploration du Parc National Albert (fasc. 3. Inst. des Parcs Nat. du Congo Belge, Brussels, 1956), J. Heinzelin and H. Mollaret have written an introductory account of the "Biotopes de Haute Altitude Ruwenzori, I". The localities inspected, mostly at an eltitude of 4,000 metres and above, are seldom visited, except perhape by native hunters, the more so as there is no season when good weather, and therefore travelling conditions, can be assured. There are, however, brief periods, for example, during January-February, when for a fow weeks mist and rainfall may be such as to admit of travel and observation. The equipment used during the expedition is described, and then follow notes and diagrams on selected biotopes, that is, localities in which particular biological materials are to be observed. The monograph is illustrated by some excellent photographs-some in colour-those of the high mountain lakes being of a particular fascination. The main cartographical observations from the present and from earlier surveys of the high massifs of Ruwenzori have been brought together in a new map. Some brief floristic and faunistic notes are given. 